\title{
Subsurface Drip Irrigation Reduced Nitrous Oxide Emissions in a Pomegranate Orchard
}

\author{
Suduan Gao, Aileen Hendratna, Zejiang Cai, Yinghua Duan, Ruijun Qin, and Rebecca Tirado-Corbalá
}

\begin{abstract}
Soil fertilization is one of the major sources for nitrous oxide $\left(\mathrm{N}_{2} \mathrm{O}\right)$ emissions and soil moisture is among the most important factors affecting its production. Thus, one of the important mitigation strategies in semiarid or arid regions is through irrigation and/or fertigation management. The objective of this research was to evaluate the effects of different drip irrigation methods and $\mathrm{N}$ application levels on $\mathrm{N}_{2} \mathrm{O}$ emissions. Nitrous oxide emission flux and $\mathrm{N}_{2} \mathrm{O}$ concentration in soil profile were measured in a pomegranate field for two growing seasons under two irrigation systems [subsurface drip irrigation (SDI) at $\sim 0.5 \mathrm{~m}$ depth and traditional surface drip irrigation (DI)], and three $\mathrm{N}$ application rates $(50 \%, 100 \%$, and $150 \%$ of current practice rate). Both years' data showed that $\mathrm{N}_{2} \mathrm{O}$ emissions has a high and positive correlation with $\mathrm{N}$ fertilization events and application levels. Nitrous oxide emissions from DI at $100 \%$ and $150 \% \mathrm{~N}$ levels were over an order of magnitude higher compared to those from SDI based on the data of the first year. Data from the second year confirmed the first year's findings of high emissions from DI. A positive linear correlation between the $\mathrm{N}_{2} \mathrm{O}$ emission flux and $\mathrm{N}_{2} \mathrm{O}$ concentration in soil-gas phase was identified that supported emission data. This research demonstrated that although $\mathrm{N}$ fertilization is a major cause for $\mathrm{N}_{2} \mathrm{O}$ emissions, subsurface drip irrigation/fertigation can lead to a significant emission reduction in addition to other benefits, such as increased water and nutrient use efficiencies, and reduced weed pressure.
\end{abstract}

Index Terms-Chemical nitrogen fertilizer, greenhouse gas emission, high-frequency drip irrigation.

\section{INTRODUCTION}

Nitrous oxide is a potent greenhouse gas (GHG) and has a global warming potential (GWP) 298 times that of an equivalent amount of carbon dioxide $\left(\mathrm{CO}_{2}\right)$ for a 100-year timescale [1]. Agricultural soils are estimated to contribute about $75 \%$ of the total U.S.A. $\mathrm{N}_{2} \mathrm{O}$ emissions. Although $\mathrm{N}_{2} \mathrm{O}$

Manuscript received January 7, 2019; revised February 14, 2019. This work was supported by the U.S. Department of Agriculture, Agricultural Research Service Base Funds. Mention of trade names or commercial products in this publication is solely for the purpose of providing specific information and does not imply recommendation or endorsement by the U.S. Department of Agriculture. USDA is an equal opportunity provider and employer.

S. Gao, and A. Hendratna are with USDA, Agricultural Research Service, San Joaquin Valley Agricultural Sciences Center, Parlier, CA, USA 93648 (e-mail: suduan.gao@ars.usda.gov, aileen.hendratna@ars.usda.gov).

Z. Cai and Y. Duan is with Institute of Agricultural Resources and Regional Planning, Chinese Academy of Agricultural Sciences, Beijing, China (e-mail: caizejiang@caas.cn, duanyinghua@caas.cn).

R. Qin is with Hermiston Agricultural Research \& Extension Center, Oregon State University, Hermiston (e-mail ruijun.qin @ oregonstate.edu).

R. Tirado-Corbalá is with Agro-Environmental Science Department, University of Puerto Rico, Mayagüez, Puerto Rico, USA (e-mail: rebecca.tirado@upr.edu). emission accounts only for 5\% of total GHG emissions, because of its high GWP and major source from agriculture, reducing $\mathrm{N}_{2} \mathrm{O}$ emissions from agricultural fields plays an important role in mitigating global warming. Evaluation of field management practices (e.g., irrigation and fertilization) would assist in the development of mitigation strategies.

Soil water content is one of the most important factors affecting $\mathrm{N}_{2} \mathrm{O}$ emissions. Nitrous oxide is produced primarily via microbial nitrification and denitrification processes. With increased soil water content, denitrification can become more significant and that led to much higher $\mathrm{N}_{2} \mathrm{O}$ emissions [2], [3] A number of studies have shown that $\mathrm{N}_{2} \mathrm{O}$ emissions were related positively to irrigation or irrigation amount [4] and increased by increasing or higher water-filled pore space (WFPS) [5], Trost et al. [6]. In forest soils, $\mathrm{N}_{2} \mathrm{O}$ emissions increased with increasing WFPS or decreasing water tension with the maximal $\mathrm{N}_{2} \mathrm{O}$ emissions measured between 80 and 95\% WFPS or $0 \mathrm{kPa}$ water tension [7]. In arable lands, higher soil moisture showed over 100 times greater $\mathrm{N}_{2} \mathrm{O}$ cumulative production at 70 WFPS than at 40 WFPS when studying cover-crop residue effects on $\mathrm{N}_{2} \mathrm{O}$ emissions [8]. However, different irrigation system affects soil moisture distribution drastically in the field. Surface drip irrigation has been found to reduce $\mathrm{N}_{2} \mathrm{O}$ emissions compared with flood irrigation [9], conventional furrow irrigation and side dress fertilization [10], and sprinkler or other irrigation systems [11]. Studies on effects of subsurface drip on GHG emissions are limited especially in orchards. Wei et al. [12] reported subsurface watering to saturate subsurface soil at $15-50 \mathrm{~cm}$ reduced $\mathrm{N}_{2} \mathrm{O}$ emissions in soil boxes. Subsurface drip at $15 \mathrm{~cm}$ soil depth in a tomato field, however, did not reduce emissions [13]. In a cotton field with raised beds, Bronson et al. [14] reported that $\mathrm{N}_{2} \mathrm{O}$ emissions ranged from $0.1-0.54 \%, 0.15-1.1 \%$, and $<0.1 \%$ of added $\mathrm{N}$ fertilizer for furrow, sprinkler, and subsurface drip irrigation (to $22-28 \mathrm{~cm}$ depth) systems, respectively. Maris et al. [15] did find SDI with drip tape 50 $\mathrm{cm}$ from tree trunks and at $20 \mathrm{~cm}$ soil depth reduced markedly $\mathrm{N}_{2} \mathrm{O}$ emissions in an olive orchard. The results from SDI with water applied to shallow soil depth varied among studies.

California (CA), which is located in the south-west corner of the continental United States of America and adjacent to the Pacific Ocean, is the nation's top agricultural production state with approximately $\$ 47$ billion output in 2015 [16]. The state's total value of all fruits and nuts was $\$ 18.1$ billion, nearly $67 \%$ of the US total value of all fruits and nuts. Most of the tree fruits and nuts are produced in the San Joaquin Valley (SJV), one of the most productive regions in the world (annual agricultural output exceeding $\$ 30$ billion). The climate in the SJV is Mediterranean with hot/dry summers and cool/moist winters. All crops in the SJV are irrigated 
during summer. Ever increasing water shortage has forced the region to consider more water efficiency strategies including improving irrigation technology and growing drought tolerant or less water demanding crops, such as pomegranate (Punica granatum L.).

A field study was conducted from 2010-2015 in the SJV to determine basic water and nitrogen $(\mathrm{N})$ requirement in a pomegranate orchard. The field treatments included two main irrigation treatments as surface drip irrigation (DI) and subsurface drip irrigation (SDI) and three $\mathrm{N}$ application rates as sub-treatments. The findings on treatment effects on yield, $\mathrm{N}$ requirement, and weed as well as $\mathrm{C}$ and $\mathrm{N}$ dynamics from this field research are reported in Ayars et al. [17] and Tirado-Corbalá et al. [18], respectively. Conclusions included that although yields were not significantly different between the two irrigation systems, SDI used less water with much lower weed pressure than DI. There was significantly higher $\mathrm{N}$ uptake in fruits from SDI at least in two out of the last three years of the study. The specific objective of this paper was to evaluate the effects of drip irrigation method and $\mathrm{N}$ application level on $\mathrm{N}_{2} \mathrm{O}$ production or emissions. Data were collected from two consecutive years (2012-2013) after the pomegranate orchard was established in 2010. We hypothesize that higher surface soil water content from DI would lead to higher $\mathrm{N}_{2} \mathrm{O}$ emissions than drier conditions from SDI.

\section{MAterials AND Methods}

\section{A. Study Site, Treatments, and Field Operation}

This research was conducted in a pomegranate orchard (1.4 ha) at the University of California, Kearney Agricultural Research and Extension Center, Parlier, CA on a Hanford sandy loam (coarse-loamy, mixed, superactive, nonacid, thermic Typic Xerorthents). The soil has a pH 7.5 (1:2 0.01 $\left.\mathrm{M} \mathrm{CaCl}_{2}\right) ; \mathrm{EC}_{25(1: 1)} 171 \mu \mathrm{S} \mathrm{cm} \mathrm{cm}^{-1}$; and field capacity $\sim 17 \%$. The orchard was established in 2010 by planting pomegranate trees (var. Wonderful) and continued for five years. Detailed information about the field set up can be found in Ayars et al. [17]. Briefly, the field experiment included two main irrigation treatments: DI and SDI, and three sub-treatments $\mathrm{N}$ application rates of 50, 100, and $150 \%$ of current practice for a total six treatments in five replications (blocks) in a split-plot design. Each plot consisted of three tree rows with a row spacing of $4.9 \mathrm{~m}$ and each row had total 7 trees with a tree spacing of $3.6 \mathrm{~m}$ (total 567 trees $\mathrm{ha}^{-1}$ ). All trees received uniform application of fertilizers during the first two years (2010-2011) of growth to ensure uniform stand prior to treatments. The different fertilization treatments started in 2012. For all treatments, fertilizers were applied through irrigation system (fertigation).

Two irrigation drip lines (laterals) (one on each side of the tree) were installed at a distance of $1.1 \mathrm{~m}$ from the row at soil surface for the DI and at soil depth of 50-55 cm for the SDI. Irrigation was applied after $1 \mathrm{~mm}$ of crop water use measured in a lysimeter located in the field, which resulted in high irrigation frequency (8-12 times per day during summer time). To compensate for higher evaporation loss, DI treatments received $10 \%$ more water than SDI starting in 2012. To investigate the moisture distribution pattern under the two irrigation systems, soil samples were collected on 6 August 2012 by sampling soils to $1 \mathrm{~m}$ depth at $20 \mathrm{~cm}$ increment and water content was determined using gravimetric method.

For N fertilization, N-pHURIC ${ }^{\circledR} 10 / 55$ (urea and sulfuric acid with $10 \% \mathrm{~N}$ and $18 \% \mathrm{~S}$ ) was applied through irrigation system to all $\mathrm{N} 1, \mathrm{~N} 2$, and $\mathrm{N} 3$ treatments and to maintain irrigation water $\mathrm{pH}$ at 6.5 to avoid precipitation of phosphates. For the additional $\mathrm{N}$ requirement, ammonium nitrate $(20 \% \mathrm{~N}$ or AN20) was injected to N2 and N3 treatments. For P and K supply, phosphoric acid $\left(\mathrm{H}_{3} \mathrm{PO}_{4}\right)$ and potassium thiosulfate $\left(25 \% \mathrm{~K}\right.$ from $\mathrm{K}_{2} \mathrm{O}$ and $17.5 \% \mathrm{~S}$ ) were injected to all treatments at irrigation water concentrations of $15-20 \mathrm{mg} \mathrm{L}^{-1}$ for $\mathrm{P}$ and $50 \mathrm{mg} \mathrm{L}^{-1}$ for $\mathrm{K}$ (refer to Ayars et al. [17] for details). Fertilizer application began in late April or early May through August for both 2012 and 2013. Total N applied during the growing season was 52,165 and $279 \mathrm{~kg} \mathrm{ha}^{-1}$ for 2012, and 71, 166, and $244 \mathrm{~kg} \mathrm{ha}^{-1}$ for 2013, in N1, N2, and N3 treatments, respectively. Nitrogen application schedule can be shown by the irrigation water $\mathrm{N}$ concentration in Fig. 1a and Fig. 1b for 2012, and 2013, respectively. In 2013, however, there was an interruption in fertilization for approximately one month starting in early June due to a pump failure, which resulted in no fertilizer application during this period of time for all treatments. Since the pump was repaired towards the end of the growing season, only small amounts of $\mathrm{N}$ were applied at similar rates to all treatment plots. Thus, $\mathrm{N}$ application among the three $\mathrm{N}$ levels were different only during the first month of the growing season in 2013.

\section{B. Field Sampling and Analyses for $\mathrm{N}_{2} \mathrm{O}$ Emissions and Production in Soil Profile}

Nitrous oxide data were collected for all six treatments during both 2012 and 2013. One tree near the middle of a treatment plot (total 7 trees) was selected for field sampling. The first year's data were collected from one replicate due to lack of personnel for sampling in the large orchard. After significant differences between the treatments were observed, we decided to collect data for the second year from two treatment blocks to confirm the first year's findings. To further verify that the data collected were representative for evaluating the treatment effects, certain dates were selected for collecting data from three replicates when possible. Sampling during each year was conducted before irrigation/fertigation and continued through the growing season. The measurements were carried out between 9:00-12:00 for each day sampling. Thus, the flux data were suitable for evaluation of treatment effects rather than estimates for cumulative or total emissions.

Nitrous oxide emissions were measured using passive chamber method. Briefly, during $\mathrm{N}_{2} \mathrm{O}$ sampling, the chamber was placed on a chamber base that was inserted into soil for approximate $5 \mathrm{~cm}$ depth. Upon closure of the chamber (i.e., by sealing the chamber top to the chamber base) $20 \mathrm{~mL}$ of gas inside the chamber were collected using gas-tight syringes every $30 \mathrm{~min}$ for up to 1.5 hours and during this period of time, a linear increase of $\mathrm{N}_{2} \mathrm{O}$ concentration inside the chamber was observed upon closure. The sampling was done 
manually in 2012, but in 2013 an auto-sampler was used. The auto-sampler design, sampling protocol, laboratory analysis, and data processing for $\mathrm{N}_{2} \mathrm{O}$ flux are described in Gao et al. [19]. Each gas sample was preserved by injecting into $10 \mathrm{~mL}$ glass headspace vials that were previously flushed with ultra-zero grade air to reduce background $\mathrm{N}_{2} \mathrm{O}$ level. The $\mathrm{N}_{2} \mathrm{O}$ concentration was analyzed on a gas chromatograph (6890N GC) using a headspace sampler (G1888), a HP-PLOT Q column, and a micro electron capture detector from Agilent Technologies (Santa Clara, CA, USA). Emission flux (f, $\mu \mathrm{g} \mathrm{m}^{-2} \mathrm{~h}^{-1}$ ) was calculated from the linear model:

$$
f=\frac{V d C}{A d t}=b h
$$

where $d C / d t$ is the slope $\left(b, \mu \mathrm{g} \mathrm{N} \mathrm{m}{ }^{-3} \mathrm{~h}^{-1}\right)$ of the linear equation by plotting $\mathrm{N}_{2} \mathrm{O}$ concentration vs. time, and $\mathrm{h}$ is the effective chamber height $(\mathrm{m})$, which is the ratio of the chamber volume $\left(V, \mathrm{~m}^{3}\right)$ to the surface area $\left(A, \mathrm{~m}^{2}\right)$ covered by the chamber. During measurement, the chamber base was inserted to the soil above the drip lines for SDI. For the DI treatment plots, the base was installed over the drip line by cutting the bottom half edge where the drip line ought to be and burying the drip line slightly below the base.

At the same location where the chamber was installed, stainless steel capillary tubes were installed near but outside of the chamber base at soil depths of $15,30,45,60$, and 100 $\mathrm{cm}$. Sampling of the $\mathrm{N}_{2} \mathrm{O}$ in the profile was done at the same time when the emission samples were collected. Sample preservation and analysis were the same as the emission samples.

\section{Data Analysis}

When data were measured from three replicates (e.g., $\mathrm{N}_{2} \mathrm{O}$ emission measurements from selected dates; soil water content distribution), statistical analyses were conducted using SAS ${ }^{\circledR}$ software 9.4 [20]. A mixed model analysis was performed followed by mean separation using Tukey's adjustment at $P<0.05$.

\section{RESUlTS AND DisCUSSION}

\section{A. $\mathrm{N}_{2} \mathrm{O}$ Emissions}

Results of the $\mathrm{N}_{2} \mathrm{O}$ emission flux during 2012 and 2013 growing seasons in the pomegranate orchard are shown in Fig. 1. Both years' data clearly showed that chemical N fertilizer application during growing season caused significant increase in $\mathrm{N}_{2} \mathrm{O}$ emission rates. Emissions were extremely low before fertilizer application started in spring and after fertilizer application stopped in the fall. Secondly, SDI resulted in much lower $\mathrm{N}_{2} \mathrm{O}$ emissions than DI. In 2012, $\mathrm{N} 2$ and N3 treatments with DI resulted in the highest emissions (up to $800 \mu \mathrm{g} \mathrm{m}^{-2} \mathrm{~h}^{-1}$ ). The lowest $\mathrm{N}$ application (N1) showed negligible emissions under DI. The $\mathrm{N}_{2} \mathrm{O}$ emission rates from SDI plots were all below $10 \mu \mathrm{g} \mathrm{N} \mathrm{m}^{-2} \mathrm{~h}^{-1}$ throughout the season regardless of $\mathrm{N}$ application rates. The data indicate that $\mathrm{N}_{2} \mathrm{O}$ emission is indeed highly associated with $\mathrm{N}$ fertilization and significantly impacted by irrigation method. The results indicate $\mathrm{N}$ transformation from fertilization and high surface water content were the two factors leading to high $\mathrm{N}_{2} \mathrm{O}$ emissions.

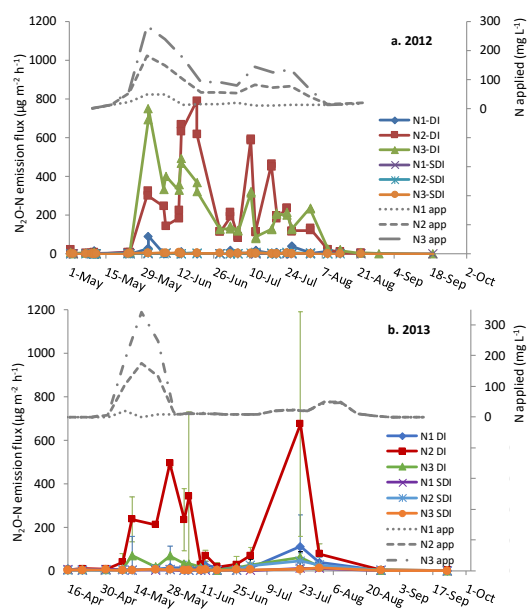

Fig. 1. Nitrous oxide emissions from a pomegranate field (a) 2012, (b) 2013. Treatments: DI=surface drip irrigation, SDI=subsurface irrigation, N1, N2, and N3=50\% $\left(N=52-70 \mathrm{~kg} \mathrm{ha}^{-1}\right), 100 \%\left(N=165-166 \mathrm{~kg} \mathrm{ha}^{-1}\right)$, and150\% $\left(N=245-279 \mathrm{~kg} \mathrm{ha}^{-1}\right)$ in 2012-2013 in reference to common practices. Error bars for 2013 data are standard deviations of the mean $(n=2)$.

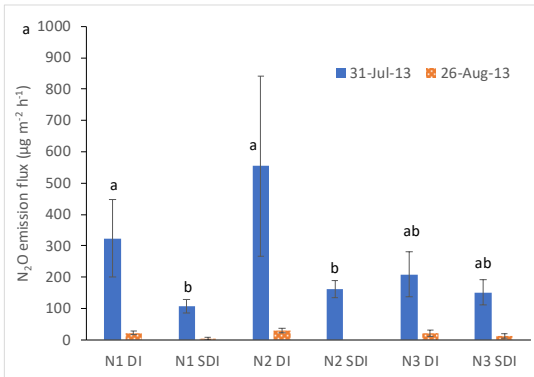

Fig. 2. Nitrous oxide emissions measured from three replicate plots on selected dates in 2013 in a pomegranate field. DI and SDI refer to surface drip and subsurface drip irrigation respectively; N1, N2, and N3 refer to $\mathrm{N}$ application at $50 \%, 100 \%$, and $150 \%$ in reference to common practices. Error bars are standard error of the mean $(n=3)$.
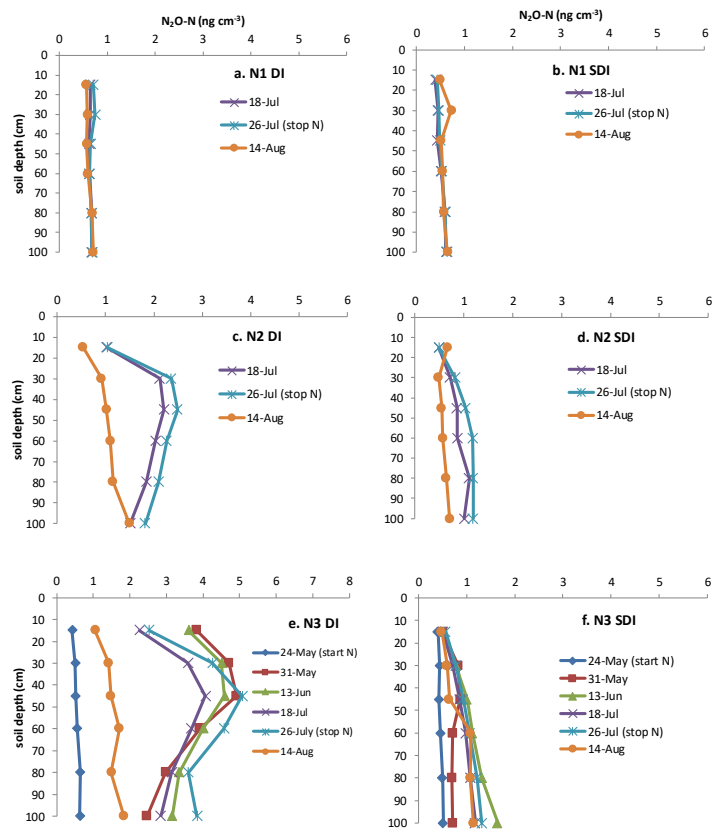

Fig. 3. Nitrous oxide concentration in soil gas-phase during 2012 growing season in a pomegranate field. DI and SDI refer to surface drip and subsurface drip irrigation respectively; $\mathrm{N} 1, \mathrm{~N} 2$, and $\mathrm{N} 3$ refer to $\mathrm{N}$ application at $50 \%, 100 \%$, and $150 \%$ in reference to common practices. 


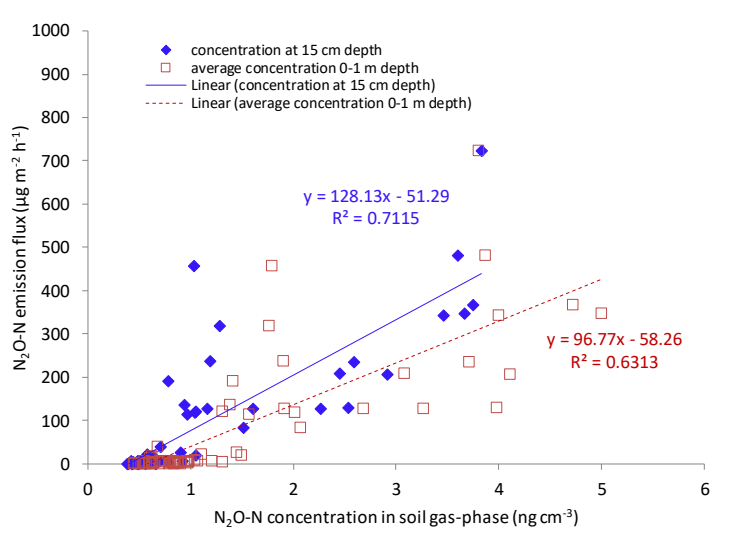

Fig. 4. Positive correlations between $\mathrm{N}_{2} \mathrm{O}$ emission flux and $\mathrm{N}_{2} \mathrm{O}$ concentration in soil gas-phase at either surface soil $(15 \mathrm{~cm}$ depth) or average of soil profile $(0-1 \mathrm{~m})$.

In 2013, $\mathrm{N}_{2} \mathrm{O}$ emission data showed high variability, but the higher emissions were consistently shown from DI with the highest from N2 treatment. The failure of pump that was controlling fertilization between late May and middle June caused low emission from all treatments during this period of time. Although the second peak emission rate in middle of July was from N2 DI, large variation was observed between the two replicates that must have been influenced by local soil moisture conditions and/or preexisting $\mathrm{N}$ conditions at the monitoring locations. The data generally show higher $\mathrm{N}_{2} \mathrm{O}$ emission rates from higher $\mathrm{N}$ application rates under DI and the difference between N2 and N3 was not apparent. Higher emissions from DI than SDI indicate a significant shift in microbial communities that might have contributed to the highly variable $\mathrm{N}_{2} \mathrm{O}$ emissions. Gaseous concentration data in soil (see section below) indicated that the monitoring location in $\mathrm{N} 2$ treatment had much higher $\mathrm{N}_{2} \mathrm{O}$ productions. Overall, the data from the second year showed again that all SDI treatments had much lower $\mathrm{N}_{2} \mathrm{O}$ emissions than those from DI. Measurements from three replicates at two selected times also showed that DI had significantly higher $\mathrm{N}_{2} \mathrm{O}$ emission flux than that from SDI (Fig. 2) at least at two N application levels, which was consistent for the sampling dates. At both sampling dates, application of $\mathrm{N}$ was not different among the three $\mathrm{N}$ levels (Fig. 1b), thus the differences in the $\mathrm{N}_{2} \mathrm{O}$ flux were mainly attributed to different irrigation methods. The no significant differences among all three $\mathrm{N}$ levels at either DI or SDI also support this conclusion.

\section{B. $\mathrm{N}_{2} \mathrm{O}$ Production in Soil and Correlation with Emission Flux}

The $\mathrm{N}_{2} \mathrm{O}$ concentration in soil profile was found to highly correlate with $\mathrm{N}_{2} \mathrm{O}$ emission flux. Changes of $\mathrm{N}_{2} \mathrm{O}$ concentrations in soil during the growing season in 2012 are shown in Fig. 3. Immediate sampling following the first fertilizer injection on May 24 showed low soil $\mathrm{N}_{2} \mathrm{O}$ concentrations. Within a few days and continuous fertilization on $31^{\text {st }}$ of May, much higher concentration was measured throughout the soil profile at the N3 level (Fig. 3 e,f). The concentrations then decreased with time until another fertilization. The last fertilizer application was on 26 of July when the highest $\mathrm{N}_{2} \mathrm{O}$ concentrations in soil profile were measured in all treatments, but the concentrations were then drastically reduced by mid-August. In general, $\mathrm{N}_{2} \mathrm{O}$ concentrations in soil were higher in DI plots compared to SDI at the same application rate except very little differences at the $\mathrm{N} 1$ rate.

Fig. 3 shows that the $\mathrm{N}_{2} \mathrm{O}$ production in soil followed two different distribution patterns under the two irrigation methods. From DI, $\mathrm{N}_{2} \mathrm{O}$ concentrations were higher (highest in N3 treatment) in surface soil (at 30 or $40 \mathrm{~cm}$ depth). The lower concentrations measured at $15 \mathrm{~cm}$ depth was due to faster physical transport through the soil-air interface to the atmosphere. The concentration decreased as the depth increased below the highest concentration. For the SDI, however, $\mathrm{N}_{2} \mathrm{O}$ concentration was low in surface and tended to increase with soil depth. These were due to $\mathrm{N}$ application at surface for DI, but in subsurface for SDI. Tirado-Corbalá et al. [18] showed that dissolved organic carbon (DOC) and nitrate concentrations under the SDI were higher in subsurface soils (below $30 \mathrm{~cm}$ ) than surface soil compared to those under DI with higher concentrations in upper soil depths. The data support that microbial reactions could occur in subsurface and explained why $\mathrm{N}_{2} \mathrm{O}$ concentration could increase with soil depth in subsurface soil under SDI. However, Tirado-Corbalá et al. [18] also showed that the SDI soil at N1 and N2 levels did not result in elevated TN and $\mathrm{NO}_{3}{ }^{-}$concentrations at $105-120 \mathrm{~cm}$ soil depth suggesting reduced leaching risk using the high frequency irrigation. Both Ayars et al. [17] and Tirado-Corbalá et al. [18] have demonstrated that $\mathrm{N} 3$ treatment provided unnecessarily high $\mathrm{N}$ for the pomegranate demand. Overall, the lower soil $\mathrm{N}_{2} \mathrm{O}$ concentration in SDI plots than that from DI may also be due to more efficient plant uptake. Tirado-Corbalá et al. [18] showed that total $\mathrm{N}$ uptake in fruits were significantly higher in SDI plots than that from DI at least for two out of three years. 2013 data (not shown) were similar to those collected in 2012 in distribution patterns except that the N3 treatment plots showed either lower or similar $\mathrm{N}_{2} \mathrm{O}$ concentrations as the $\mathrm{N} 2$ treatment plots that were consistent with the emission data.

A positive correlation between $\mathrm{N}_{2} \mathrm{O}$ emission flux and soil gas $\mathrm{N}_{2} \mathrm{O}$ concentration is identified for both 2012 and 2013. Fig. 4 shows 2012 data by plotting emission flux vs both surface soil $\mathrm{N}_{2} \mathrm{O}$ concentration and the average concentration in the soil profile $(0-1 \mathrm{~m}$ depth). This positive correlation indicates that $\mathrm{N}_{2} \mathrm{O}$ emissions from soil surface could be predicted from soil gaseous concentration in soil profile and soil physical properties that determine transport processes.

\section{Mitigation of $\mathrm{N}_{2} \mathrm{O}$ Emission through Irrigation and Fertilization Management}

The field data indicate that high frequency SDI and fertigation can effectively reduce $\mathrm{N}_{2} \mathrm{O}$ emissions in comparison with the conventional DI. At the same $\mathrm{N}$ application level, $\mathrm{N}_{2} \mathrm{O}$ emission rates from DI were always much higher than SDI based on the two years' field measurement (Fig. 1). The higher emission rates from DI were attributed to the large differences in soil moisture condition in surface soil in addition to the $\mathrm{N}$ supply, i.e., the wet surface in DI and drier surface in SDI are one of the critical factors contributing to the differences in $\mathrm{N}_{2} \mathrm{O}$ emissions. Wang et al. [21] reported that increased soil 
moisture stimulated the growth of ammonia-oxidizing bacteria and nitrite reducer (nirK) and total $\mathrm{N}_{2} \mathrm{O}$ emissions were positively correlated to ammonia-oxidizing bacteria abundance. The SDI also resulted in higher water use efficiency and much lower weed pressure Ayars et al. [17] as well as higher $\mathrm{N}$ use efficiency Tirado-Corbalá et al. [18]. All the benefits plus the reduced $\mathrm{N}_{2} \mathrm{O}$ emissions in this study make SDI preferable to the DI. Edwards et al. [13] did not find significant difference in $\mathrm{N}_{2} \mathrm{O}$ emissions between SDI and DI from a tomato field because the drip tape in their study was buried at a much shallower depth $(15 \mathrm{~cm}$ depth below the surface) compared to the $\sim 50 \mathrm{~cm}$ depth in our study. They did illustrate that higher surface soil moisture from DI resulted in significantly higher seasonal $\mathrm{CO}_{2}$ emissions than SDI. All data indicate that to reduce $\mathrm{N}_{2} \mathrm{O}$ emissions, drip irrigation may need to be applied below a certain soil depth, which may vary among soil types or crop production systems, an area that needs further investigations.

The higher surface soil moisture and fertilizer application to surface soil from DI are the major causes for stimulated microbial activities that lead to much higher emissions in comparison with SDI. Applied $\mathrm{N}$ is subject to either nitrification or denitrification and through both $\mathrm{N}_{2} \mathrm{O}$ can be produced and the process is highly correlated with oxygen $\left(\mathrm{O}_{2}\right)$ pressure or WFPS. Nitrification rates were reduced by a factor of 6-9 when $\mathrm{O}_{2}$ decreased from 20.4 to $0.35 \mathrm{kPa}$.

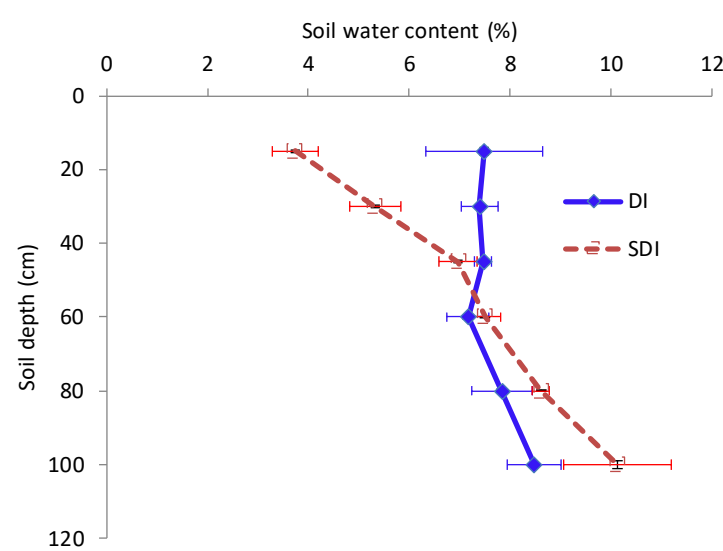

Fig. 5. Different distribution in soil water content between DI and SDI. Measurement was made on 6 August 2012, during the growing season.

Khalil et al. [2]. Many studies have observed the increased $\mathrm{N}_{2} \mathrm{O}$ emissions as soil moisture or WFPS increased Dobbie et al. [5], Schindlbacher et al. [7], Trost et al. [6], and Pimentel et al. [8]. This relationship was further examined under well controlled conditions by Cai et al. [3] who found two distinctly different linear correlations between $\mathrm{N}_{2} \mathrm{O}$ emission and soil nitrite (a precursor for $\mathrm{N}_{2} \mathrm{O}$ ) concentration with a much deeper slope for soil moisture above water holding capacity than that below. In the current study, significantly higher soil water content in DI than that from SDI in soil depth above $40 \mathrm{~cm}$ was determined (Fig. 5). All data suggest that drip tapes buried at certain depth to produce significantly drier condition in top $30 \mathrm{~cm}$ can reduce $\mathrm{N}_{2} \mathrm{O}$ emissions.

Effective $\mathrm{N}$ management is another key to reducing $\mathrm{N}_{2} \mathrm{O}$ emissions. Both $\mathrm{N}$ source and application rate have significant impact on $\mathrm{N}_{2} \mathrm{O}$ production, thus can be managed to reduce $\mathrm{N}_{2} \mathrm{O}$ emissions. An integrated system (drip irrigation, reduced tillage, and fertigation) has shown to significantly reduce $\mathrm{N}_{2} \mathrm{O}$ emissions by $>70 \%$ in comparison with the conventional (furrow irrigation and sidedress fertilizer injection) [10]. Under DI, fertilizer types also affect surface emissions of $\mathrm{N}_{2} \mathrm{O}$ in an almond orchard, which were estimated as: high frequency irrigation or $\mathrm{HF}$ with urea and ammonium nitrate $(\mathrm{UAN})>$ standard $\left(4 \times\right.$ year $\left.^{-1}\right) \mathrm{UAN}>\mathrm{HF}$ $\mathrm{NO}_{3}{ }^{-}$[22]. They also found that $\mathrm{N}_{2} \mathrm{O}$ production was highest at $10-15 \mathrm{~cm}$ depth and reduced below $20 \mathrm{~cm}$ depth, which agrees with our observations (Fig. 2). Many studies, e.g., Lebender et al. [23], Cai et al. [3], have reported the emissions increase as $\mathrm{N}$ application increases. Applying $\mathrm{N}$ based on plant needs and avoiding excessive $\mathrm{N}$ supply in soil not only minimize $\mathrm{N}_{2} \mathrm{O}$ emissions, but also reduce leaching and losses via other pathways. The worst scenario for $\mathrm{N}_{2} \mathrm{O}$ emissions is the combination of high moisture and $\mathrm{N}$ application to surface soil. Thus, any practice that prevents high $\mathrm{N}$ input directly to surface soil and high moisture building-up would minimize $\mathrm{N}_{2} \mathrm{O}$ emissions. These findings should apply to all irrigation systems regardless of crop types.

Although this research illustrated differences in $\mathrm{N}_{2} \mathrm{O}$ emission flux between the DI and SDI systems in a pomegranate orchard, there are remaining questions or further investigations that are needed. We used both DI and SDI with HF irrigation in this study. As SDI technology has not been adopted in many places and DI is still used widely, the higher $\mathrm{N}_{2} \mathrm{O}$ emissions from DI can be reduced by reduced irrigation frequency. From a two-year study, Fentabil et al. [24] showed that irrigation every $2^{\text {nd }}$ day reduced area-scaled emissions by $27 \%$ compared to irrigation every day and mulching also reduced emissions by $19 \%$. Using $\mathrm{N}$ transformation inhibitors e.g., Cai et al. [3], or controlled-release fertilizer, e.g., Braun and Bremer [4], has been reported to reduce emission in many studies. Also, we only measured emissions from drip lines close to the trees. There are significant spatial differences based on the distance from the drip tape or emitters in orchards. Pang et al. [25] showed that in addition to the seasonal pattern (high in hot-humid summer and low in cold-dry winter), annual average $\mathrm{N}_{2} \mathrm{O}$ emissions were the highest at $0.5 \mathrm{~m}$ distance from trees in a non-irrigated apple orchard. In an irrigated orchard that is similar to our study conditions, relatively higher $\mathrm{N}_{2} \mathrm{O}$ fluxes were frequently observed in tree rows compared to the tractor rows during growing seasons [26], [27]. These seasonal and spatial variations as well as fertilization, rainfall, and irrigation events must be taken into account to estimate total $\mathrm{N}_{2} \mathrm{O}$ emissions and develop mitigation strategies in orchards. As many factors and processes are affecting $\mathrm{N}_{2} \mathrm{O}$ emissions, integrative approaches, such as those outlined by Hatfield [28] should always be emphasized in management practices under specific environments.

\section{CONCLUSIONS}

Two year's field data from the pomegranate orchard consistently demonstrated that high frequency SDI and fertigation at about $0.5 \mathrm{~m}$ depth below soil surface resulted in much lower $\mathrm{N}_{2} \mathrm{O}$ emissions compared to the conventional DI. 
Subsurface drip irrigation allows fertilizer and water application to deeper depth and the relatively drier soil surface reduces biological activities that led to low $\mathrm{N}_{2} \mathrm{O}$ production with more efficient use of water and nutrients. With increasing shortage of water supply for agriculture, SDI provides a more resource efficient strategy in orchard management. The benefits to improve water/nutrient use efficiency and reducing weed pressure in orchards as well as reducing GHG emissions makes SDI a promising technology to enhance the long-term sustainability of irrigated agriculture. The findings are believed to be applicable to all irrigated agriculture.

\section{ACKNOWLEDGEMENTS}

We would like to express our appreciation to Dr. C.J. Phene (SDI+ Consultant, Clovis, CA, USA 93613) for establishing the field project and managing the field operation that made this research possible. Our thanks also go to Mr. Tom J. Pflaum (Emeritus, Chemist, USDA, Agricultural Research Service, San Joaquin Valley Agricultural Sciences Center, Parlier, CA, USA 93648) for his insight and construction of the autosamplers for sampling nitrous oxide emissions as well as his help reviewing and editing the manuscript.

\section{REFERENCES}

[1] USEPA. (2017). Overview of greenhouse gases. [Online]. Available: https://www.epa.gov/ghgemissions/overview-greenhouse-gases

[2] K. Khalil, B. Mary, and P. Renault, "Nitrous oxide production by nitrification and denitrification in soil aggregates as affected by $\mathrm{O}_{2}$ concentration," Soil Biol. Biochem., vol. 36, issue 4, pp. 687-699, April 2004.

[3] Z. Cai, S. Gao, A. Hendratna, Y. Duan, M. Xu, and B. D. Hanson, "Key factors, soil $\mathrm{N}$ processes, and nitrite accumulation affecting nitrous oxide emissions," Soil Sci. Soc. Am. J., vol. 800, no. 6, pp. 1560-1571, November 17, 2016.

[4] R. C. Braun and D. J. Bremer, "Nitrous oxide emissions from turfgrass receiving different irrigation amounts and nitrogen fertilizer forms," Crop Sci., vol. 58, no. 4, pp. 1762-1775, May 10, 2018.

[5] K. E. Dobbie, I. P. McTaggart, and K. A. Amith, "Nitrous oxide emissions from intensive agricultural systems: Variations between crops and seasons, key driving variables, and mean emission factors," $J$. Geophys. Res., vol. 104, issue D21, pp. 26891-26899, November 20, 1999.

[6] B. Trost, H. Klauss, A. Prochnow, and K. Drastig, "Nitrous oxide emissions from potato cropping under drip-fertigation in eastern Germany," Arch. Agron. Soil Sci., vol. 60, issue 11, pp. 1519-1531, published online April 6, 2014.

[7] A. Schindlbacher, S. Zechmeister-Boltenstern, and K. Butterbach-Bahl, "Effects of soil moisture and temperature on $\mathrm{NO}, \mathrm{NO}_{2}$, and $\mathrm{N}_{2} \mathrm{O}$ emissions from European forest soils," J. Geophys. Res., vol. 109, issue D17, p. D17302, September 2, 2004.

[8] L. G. Pimentel, D. A. Weiler, G. M. Pedroso, and C. Bayer, "Soil $\mathrm{N}_{2} \mathrm{O}$ emissions following cover-crop residues application under two soil moisture conditions," J. Plant Nutr. Soil Sci., vol. 178, issue 4, pp. 631-640, May 15, 2015.

[9] D. Tian, Y. Zhang, Y. Mu, Y. Zhou, C. Zhang, and J. Liu, "The effect of drip irrigation and drip fertigation on $\mathrm{N} 2 \mathrm{O}$ and $\mathrm{NO}$ emissions, water saving and grain yields in a maize field in the North China Plain," Sci. Total Environ., vol. 575, pp. 1034-1040, January 1, 2017.

[10] T.L. Kennedy, E.C. Suddick, and J. Six, "Reduced nitrous oxide emissions and increased yields in California tomato cropping systems under drip irrigation and fertigation," Agr. Ecosys. Environ., vol. 170, pp. 16-27, April 15, 2013.

[11] G. Wang, Y. Liang, Q. Zhang, S. K. Jha, Y. Gao, X. Shen, J. Sun, and A. Duan, "Mitigated $\mathrm{CH}_{4}$ and $\mathrm{N}_{2} \mathrm{O}$ emissions and improved irrigation water use efficiency in winter wheat field with surface drip irrigation in the North China Plain," Agr. Water Manag., vol. 163, pp. 403-407, January 1, 2016.
[12] Q. Wei, J. Xu, S. Yang, L. Liao, G. Jin, Y. Li, and F. Hameed, "Subsurface watering resulted in reduced soil $\mathrm{N}_{2} \mathrm{O}$ and $\mathrm{CO}_{2}$ emissions and their global warming potentials than surface watering," Atmos. Environ., vol. 173, pp. 248-255, January 2018.

[13] K. P. Edwards, C. A. Madramootoo, J. K. Whalen, V. I. Adamchuk, A. S. M. Su, and H. Benslim, "Nitrous oxide and carbon dioxide emissions from surface and subsurface drip irrigated tomato fields," Can. J. Soil Sci., vol. 98, no. 3, pp. 389-398, April 9, 2018.

[14] K. F. Bronson, D. J. Hunsaker, C. F. Williams, K. R. Thorp, S. M. Rockholt, S. J. Del Grosso, R. T. Venterea, and E. M. Barnes, "Nitrogen management affects nitrous oxide emissions under varying cotton irrigation systems in the Desert Southwest, USA," J. Environ. Qual., vol 47, no. 1, pp. 70-78, January 2018.

[15] S. C. Maris, M. R. Teira-Esmatges, A. Arbonés, and J. Rufat, "Effect of irrigation, nitrogen application, and a nitrification inhibitor on nitrous oxide, carbon dioxide and methane emissions from an olive (Olea europaea L.) orchard," Sci. Total Environ., vol. 538, pp. 966-978, December 15, 2015

[16] California Department of Food and Agriculture (CDFA), "Agricultural statistics review, 2015-2016," CDFA, Sacramento, CA, 2017.

[17] J. E. Ayars, C. J. Phene, R. C. Phene, S. Gao, D. Wang, K. R. Day, and D. J. Makus, "Determining pomegranate water and nitrogen requirements with drip irrigation," Agr. Water Manage., vol. 187, pp. 11-23, June 2017.

[18] R. Tirado-Corbalá, S. Gao, J. E. Ayars, D. Wang, C. J. Phene, and R. C. Phene, "Carbon and nitrogen dynamics affected by different irrigation and fertilization practices in a pomegranate orchard," Agr. Water Manag.

[19] S. Gao, A. Hendratna, and T. J. Pflaum, "An inexpensive automatic sampler with static chambers for nitrous oxide emission measurement," Int. J. Environ. Sci. Dev., vol. 8, no. 1, pp. 55-61, January 2017.

[20] The data analysis for this paper was generated using SAS software. Copyright $\odot 2013$ SAS Institute Inc., SAS and all other SAS Institute Inc. product or service names are registered trademarks or trademarks of SAS Institute Inc., Cary, NC, USA.

[21] Q. Wang, Y. Liu, C. Zhang, L. Zhang, L. Han, J. Shen, and J. He, "Responses of soil nitrous oxide production and abundances and composition of associated microbial communities to nitrogen and water amendment," Biol. Fert. Soils, vol. 53, issue 6, pp. 601-611, August 2017.

[22] M. W. Wolff, J. W. Hopmans, C. M. Stockert, M. Burger, B. L. Sanden, and D. R. Smart, "Effects of drip fertigation frequency and N-source on soil $\mathrm{N}_{2} \mathrm{O}$ production in almonds," Agr. Ecosys. Environ., vol. 238, pp. 67-77, February 1, 2017

[23] U. Lebender, M. Senbayram, J. Lammel, and H. Kuhlmann, "Impact of mineral $\mathrm{N}$ fertilizer application rates on $\mathrm{N} 2 \mathrm{O}$ emissions from arable soils under winter wheat," Nutr. Cycl. Agroecosyst., vol. 100, issue 1, pp. 111-120, September 2014.

[24] M. M. Fentabil, C. F. Nichol, M. D. Jones, G. H. Neilsen, D. Neilsen, and K. D. Hannam, "Effect of drip irrigation frequency, nitrogen rate and mulching on nitrous oxide emissions in a semi-arid climate: An assessment across two years in an apple orchard," Agr. Ecosys. Environ., vol. 235, pp. 242-252, November 1, 2016.

[25] J. Pang, X. Wang, Y. Mu, Z. Ouyang, and W. Liu, "Nitrous oxide emissions from an apple orchard soil in the semiarid Loess Plateau of China," Biol. Fertil. Soils., vol. 46, issue 1, pp. 37-44, November 1 , 2009.

[26] C. Decock, G. Garland, E.C. Suddick, and J. Six, "Season and location-specific nitrous oxide emissions in an almond orchard in California," Nutr. Cycl. Agroecosyst., vol. 107, issue 2, pp. 139-155, March 2017.

[27] E. Verhoeven, E. Pereira, C. Decock, G. Garland, T. Kennedy, E. Suddick, W. Horwath, and J. Six, " $\mathrm{N}_{2} \mathrm{O}$ emissions from California farmlands: A review," Calif. Agr., vol. 71, no. 3, pp. 148-159, September 13, 2017.

[28] J. L. Hatfield, "Soil and nitrogen management to reduce nitrous oxide emissions," Soil Fertility Management in Agroecosystems, OASA, CSSA, SSSA, Madison, WI, pp. 90-109, 2017.

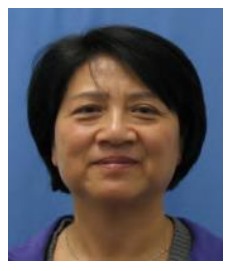

Suduan Gao is a research soil scientist in USDA, ARS SJVASC, Water Management Research Unit, located at Parlier, CA, USA. She received her MS degree in Chinese Academy of Agricultural Sciencies in 1985 and Ph.D in soil science from Universitiy of California Davis (US Davis) in 1992.

Following her Ph.D, she conducted 12 years of environmental research in UC Davis as a postodoc and 
an independent researcher. In 2004, Dr. Gao joined USDA-ARS and has been conducting research on fumigant emission reduction and efficacy as well as increasing agrochemical (e.g., nitrogen fertilizer) use efficiency and reduce environmental impact.

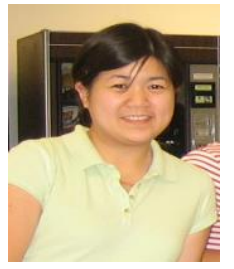

Aileen Hendratna received her MS degree in water system technology from Royal Institute of Technology, Stockholm, Sweden in 2011 and BS degree in soil and water science from University of California Davis in 2004.

She is a Biological Science Technician in USDA, ARS, SJVASC, Water Management Research Unit located at Parlier, CA, USA.

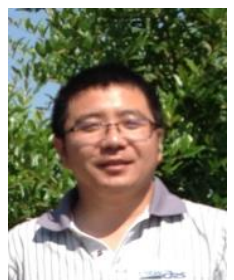

Zejiang Cai received his MS degree in soil science from Graduate School of Chinese Academy of Agricultural Sciences (CAAS), China.

$\mathrm{He}$ is research associate in Hengyang Red Soil Experimental Station of CAAS, Qiyang, Hunan province, China. He is studying the effectiveness and mechanisms of animal manures and crop straws to develop effective strategies to ameliorate soil acidity and conducted research on $\mathrm{N}_{2} \mathrm{O}$ emission and $\mathrm{N}$ transformation dynamics in soil.

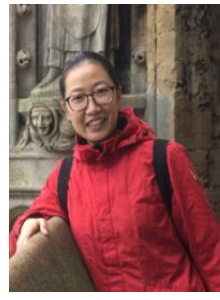

Yinghua Duan received her $\mathrm{PhD}$ in plant nutrition from Nanjing Agricultural University in 2007, China. She is an associate professor of soil science in Chinese Academy of Agricultural Science, Beijing. She worked at USDA, ARS, SJVASC, Water Management Research Unit at Parlier, CA, USA as visiting scientist in 2013 and during 2017-2018.

Her current research focuses on soil nutrient management, including nitrogen fertilizer application and soil fertility improvement. The objectives of her research are to maximum the use efficiency of nitrogen fertilizer and minimize the loss to the environment.

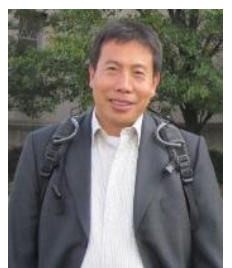

Ruijun (Ray) Qin is an assistant professor and agronomist at Oregon State University. He received his MS degree in soil science from Chinese Academy of Agricultural Sciences in 1995 and Ph.D. in agronomy from Swiss Federal Institute of Technology Zurich (ETHZ), Switzerland in 2003. He develops extension and research program focusing on field crop agronomy and soil/nutrient/water management of high value irrigated crops in north-central and north-eastern Oregon and south-central Washington, exploring environmentally sustainable and crop-effective strategies.

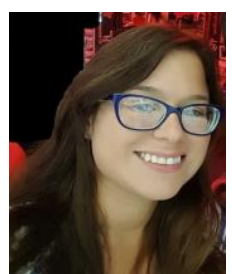

Rebecca Tirado-Corbalá received her MS from the University of Puerto Rico-Mayagüez in 2005, her $\mathrm{Ph} . \mathrm{D}$. from Ohio State University in 2010. She did her post-doc at the USDA, ARS, SJVASC, Water Management Research Unit, located at Parlier CA, USA from May 2011- January 2014.

Since 2015, she is an Assistant Researcher with the Department of Agro-environmental Sciences, Agricultural Experiment Station of the University of Puerto Rico-Mayagüez. She has been conducting research with different crops growing in tropical soils. 